\title{
Human SGBS Cells - a Unique Tool for Studies of Human Fat Cell Biology
}

\author{
Pamela Fischer-Posovszky ${ }^{a} \quad$ Felicity S. Newell ${ }^{b} \quad$ Martin Wabitsch $^{a} \quad$ Hans E. Tornqvist $^{c}$ \\ a Division of Pediatric Endocrinology and Diabetes, Department of Pediatrics and Adolescent Medicine, University of Ulm, Germany \\ ${ }^{b}$ Diamantina Institute for Cancer, Immunology and Metabolic Medicine, University of Queensland, Brisbane, Queensland, Australia \\ ${ }^{c}$ Department of Clinical Sciences, Diabetes and Endocrinology, Malmö University Hospital, Lund University, Sweden*
}

\section{Key Words}

Adipocyte · Fat cell · SGBS

\section{Summary}

The human Simpson-Golabi-Behmel syndrome (SGBS) preadipocyte cell strain provides a unique and useful tool for studies of human adipocyte biology. The cells originate from an adipose tissue specimen of a patient with SGBS. They are neither transformed nor immortalized, and provide an almost unlimited source due to their ability to proliferate for up to 50 generations with retained capacity for adipogenic differentiation. So far, the cells have been used for a number of studies on adipose differentiation, adipocyte glucose uptake, lipolysis, apoptosis, regulation of expression of adipokines, and protein translocation. The cells are efficiently differentiated in the presence of PPAR $\gamma$ agonists and in the absence of serum and albumin. SGBS adipocytes respond to insulin stimulation by increasing glucose uptake several-fold $\left(E_{50}\right.$ approximately $100 \mathrm{pmol} / \mathrm{l})$, and by very effectively inhibiting ( $\mathrm{IC}_{50}$ approximately $\left.10 \mathrm{pmol} / \mathrm{I}\right)$ catecholamine-stimulated lipolysis.
*Present Address: CVGI TA Clinical Early Development, AstraZeneca R Mölndal, 43183-Mölndal, Sweden

\section{Introduction}

Cell culture techniques offer the advantage that the effects of single factors and hormones can be studied under chemically defined conditions. This methodology is an optimal tool to elucidate mechanisms of e.g. cell development, hormone action, or metabolism. In vivo, the physiological function of a specific cell type or organ depends on its communication with the environment. As a component of a complex, highly integrated organism, adipose tissue depots interact and integrate substrate metabolism not only with surrounding but also with distant tissues. Thus, to fully understand and verify the physiological importance of any in vitro finding, it is essential to perform in vivo studies to account for cross-talk and substrate fluxes between various tissue.

The process of adipogenic differentiation as well as the metabolic and endocrine function of adipocytes has been primarily investigated in preadipocyte clonal cell lines of murine origin, which are all aneuploid. Furthermore, adipose precursor cells derived from the stromal-vascular fraction of adipose tissues from various species including humans have been used for in vitro studies in order to have a more physiological cell system. These cells are diploid but have a limited life span. An overview of cellular models of fat cell biology is given in table 1 . In general, studies on human primary preadipocytes and adipocytes have been hampered by the availability of tissue, limited supply of cells, and to some extent the variability of adipose tissue from different donors. Few human cell lines are available (table 1), and some of them have been transformed or originate from adipose tissue tumors. In 2001, we introduced the human Simpson-Golabi-Behmel syndrome (SGBS) preadipocyte cell strain which is characterized by a retained capacity to adipogenic differentiation [1]. SGBS preadipocytes proliferate in vitro for many generations. Adipogenic differentiation is achieved under serum-free culture conditions by ex-

\begin{tabular}{ll}
\hline KARGER & $\oplus$ 2008 S. Karger GmbH, Freiburg \\
Fax +49 7614520714 & Accessible online at: \\
$\begin{array}{l}\text { E-mail Information@Karger.de } \\
\text { www.karger.com }\end{array}$ & www.karger.com/ofa
\end{tabular}


Table 1. In vitro models for studying adipocyte biology

\begin{tabular}{lll}
\hline Cell line & Species & Origin \\
\hline $\begin{array}{l}\text { Totipotent } \\
\text { Embryonic stem cells }\end{array}$ & mouse & mouse blastocysts \\
\hline $\begin{array}{l}\text { Multipotent } \\
\text { 10T1/2 }\end{array}$ & & \\
3T3-F442A & mouse & mouse embryo \\
\hline Unipotent & mouse & Swiss mouse embryo (3T3 cells) \\
Immortalized hMSC & human & \\
3T3-L1 & mouse & \\
Ob17 & mouse & Swiss mouse embryo \\
TA1 & mouse & epididymal fat pad of ob/ob mouse \\
Lisa-2 & human & liposarcoma \\
\hline Cell strains & & \\
Primary & rat & WAT from all depots of newborn and adult \\
Primary & mouse & WAT from all depots of newborn and adult \\
Primary & human & WAT from all depots of newborn and adult \\
Adult stem cells & mouse, rat, human & bone marrow \\
SGBS & human & Sc WAT of an infant with SGBS \\
\hline
\end{tabular}

hMSC = Human mesenchymal stem cell. posure to a mixture of insulin, triiodothyronine, cortisol, and a PPAR $\gamma$ agonist. Even after proliferation for up to 50 generations, the cells retain their capacity for adipose differentiation as opposed to primary human preadipocytes which quickly loose their ability to differentiate when multiplied in vitro. SGBS cells have been secured and have now been multiplied into a cell bank for almost unlimited use. In the following sections, we describe the optimal differentiation procedure for human SBGS preadipocyte cells along with a summary of results of studies using human SGBS cells demonstrating how these cells have so far been used for studying adipocyte function.

\section{SGBS}

SGBS preadipocytes have been named according to their origin. The cells were originally prepared from an adipose tissue specimen of a diseased patient with SGBS. SGBS is a complex, X-linked congenital overgrowth syndrome with features that include macroglossia, macrosomia, and renal and skeletal abnormalities as well as an increased risk of embryonal cancers [2]. The majority of cases of SGBS appear to arise as a result of either deletions or point mutations within the glypican3 (GPC3) gene at Xq26, one member of a multigene family encoding for at least 6 distinct glycosylphophatidylinositollinked cell surface heparan sulfate proteoglycans [2]. However, by sequencing the entire GPC3 gene in our cell strain, we were not able to detect any mutation in CPC3 (Felicity Newell, unpublished results) suggesting a mutation in another yet unknown responsible gene [2].

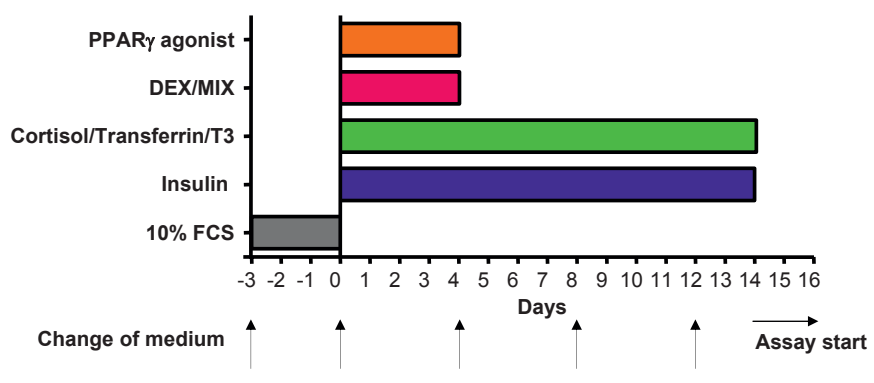

Fig. 1. Optimal differentiation protocol for human SGBS cells. Differentiation is started (day 0) by incubating cells in a serum-free differentiation medium $(2 \mu \mathrm{mol} / \mathrm{l}$ rosiglitazone, $25 \mathrm{nmol} / \mathrm{l}$ dexamethasone, $0.5 \mathrm{mmol} / \mathrm{l}$ methylisobuthylxantine, $0.1 \mu \mathrm{mol} / \mathrm{l}$ cortisol, $0.01 \mathrm{mg} / \mathrm{ml}$ transferrin, 0.2 $\mathrm{nmol} / \mathrm{l}$ triiodotyronin, and $20 \mathrm{nmol} / \mathrm{l}$ human insulin). After 4 days, medium is changed, and cells are further cultured in medium supplemented with $0.1 \mu \mathrm{mol} / \mathrm{l}$ cortisol, $0.01 \mathrm{mg} / \mathrm{ml}$ transferrin, $0.2 \mathrm{nmol} / \mathrm{l}$ triiodotyronin, and $20 \mathrm{nmol} / \mathrm{l}$ human insulin.

\section{Adipogenic Differentiation of SGBS Cells}

Over the past years, we have developed and optimized a protocol for SGBS fat cell differentiation which enables us to achieve an adipogenic differentiation rate of $>90 \%$ up to generation 50. The optimized differentiation scheme is depicted in figure 1. Typically, 5,000 cells/well at generation 30-60 (corresponding to passage 10-20) are grown in 12-well plates for 3 days to near confluence in DMEM/F12 containing 10\% fetal calf serum (FCS). The procedure was successfully scaled down to 96 - and 384-well plates. Differentiation is started (day 0 ) by washing cells 3 times with phosphate buffered saline (PBS) and then changing to a serum- and albumin-free differentia- 
Fig. 2. Adipogenic differentiation of SGBS cells.

A Microphotographs of SGBS cells during adipose differentiation cultured according to the differentiation protocol. Intracellular lipid droplets are clearly visible on culture day 7. On culture day 14 , the cells are filled with high amounts of intracellular lipids.

\section{B Markers of} adipocyte differentiation and function (mRNA expression of PPAR $\gamma$, Glut-4, aP2, leptin, adiponectin) are induced and further up-regulated during the differentiation process. One representative experiment out of 3 performed is shown.

\section{A}

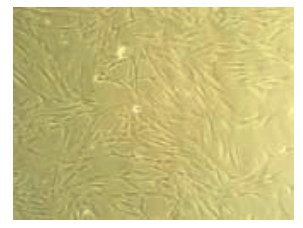

d 0

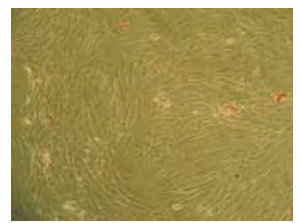

d 4

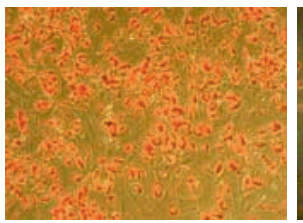

d 7

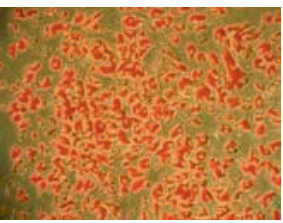

d 11

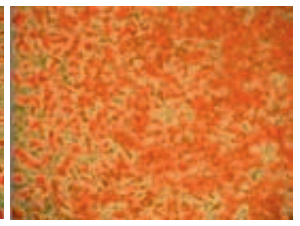

d 14
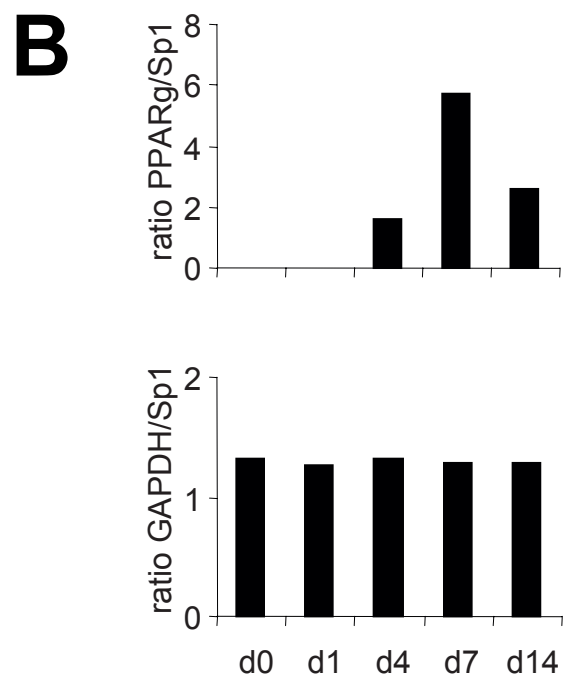
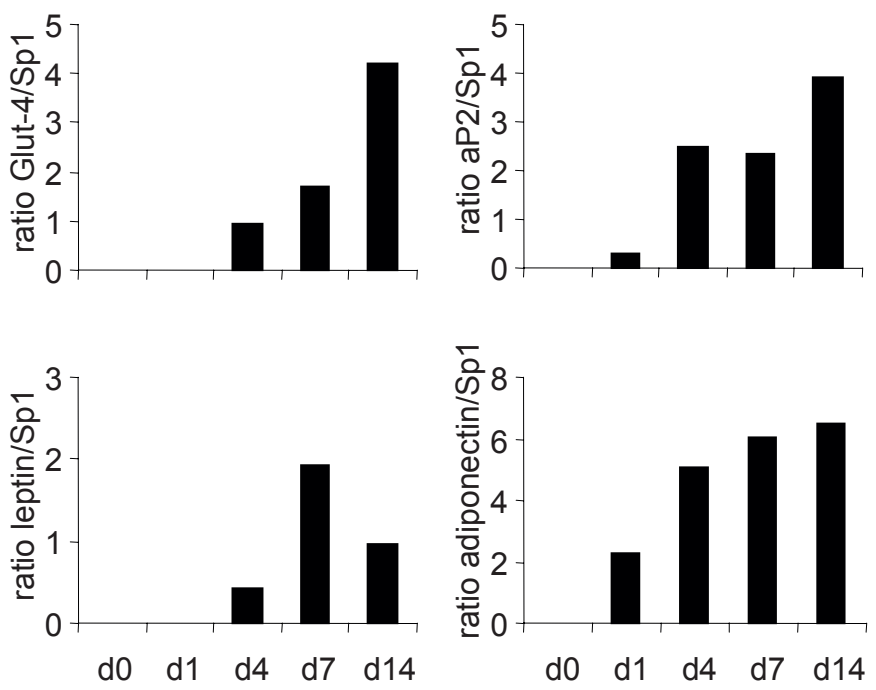

tion medium (DMEM/F12 supplemented with $2 \mu \mathrm{mol} / 1$ rosiglitazone, $25 \mathrm{nmol} / \mathrm{l}$ dexamethasone, $0.5 \mathrm{mmol} / \mathrm{l}$ methylisobuthylxantine, $0.1 \mu \mathrm{mol} / 1$ cortisol, $0.01 \mathrm{mg} / \mathrm{ml}$ transferrin, 0.2 $\mathrm{nmol} / \mathrm{l}$ triiodotyronin, and $20 \mathrm{nmol} / \mathrm{l}$ human insulin). After 4 days, medium is changed, and cells are further cultured in DMEM/F12 supplemented with $0.1 \mu \mathrm{mol} / 1$ cortisol, $0.01 \mathrm{mg} / \mathrm{ml}$ transferrin, $0.2 \mathrm{nmol} / 1$ triiodotyronin, and $20 \mathrm{nmol} / \mathrm{l}$ human insulin. Within a few days, the cells start to accumulate lipids, and small lipid droplets are visible after approximately 1 week (fig. 2 A). Typical adipocyte marker genes such as aP2, Glut-4, leptin, and adiponectin are up-regulated during the adipogenic differentiation process (fig. 2 B). Additional information on primer sequences and polymerase chain reaction (PCR) conditions is given in [1]. After 14 days, $>90 \%$ of the cells are fully differentiated showing massive triglyceride accumulation. For functional studies involving insulin, cells are washed and deprived of insulin for at least $24 \mathrm{~h}$. We want to point out that one of the major advantages of the SGBS model system is that adipogenic differentiation is performed in a chemically defined, serum- and albumin-free medium. In contrast, 3T3L1 cells are differentiated in the presence of FCS.

\section{Functional Characterization of Mature SGBS Adipocytes}

\section{PPAR $\gamma$-Dependent Differentiation}

Establishing this cell strain, we initially found that the PPAR $\gamma$ agonist rosiglitazone as well as other PPAR $\gamma$ agonists markedly potentiate differentiation of SGBS preadipocytes [1]. Under optimal conditions, triglyceride accumulation at day 7 was increased 4-fold by rosiglitazone with an $\mathrm{EC}_{50}$ of approximately $20 \mathrm{nmol} / \mathrm{l}$ (fig. $3 \mathrm{~A}$ ).

\section{Insulin-Dependent Glucose Uptake}

In fully differentiated SGBS adipocytes, following removal of insulin for $48 \mathrm{~h}$, human insulin effectively increased $\mathrm{U}-{ }^{14} \mathrm{C}$-glucose cellular uptake several-fold with an $\mathrm{EC}_{50}$ of approximately $70-110 \mathrm{pmol} / \mathrm{l}$ (fig. $3 \mathrm{~B}$ ).

\section{Isoproterenol-Stimulated Lipolysis and Anti-Lipolytic Effect} of Insulin

The effects of isoproterenol with or without insulin in crossed dose-response curves are illustrated in figure 4 . Both release of glycerol and fatty acids from the cells was measured following incubation for $4 \mathrm{~h}$ in the presence of $2 \%$ human serum albumin. Isoproterenol alone strongly induced 
A

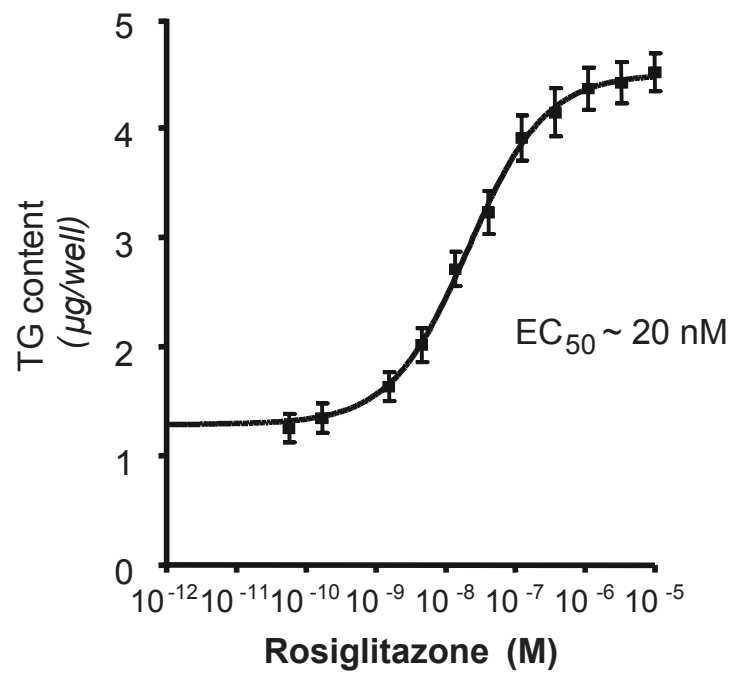

B

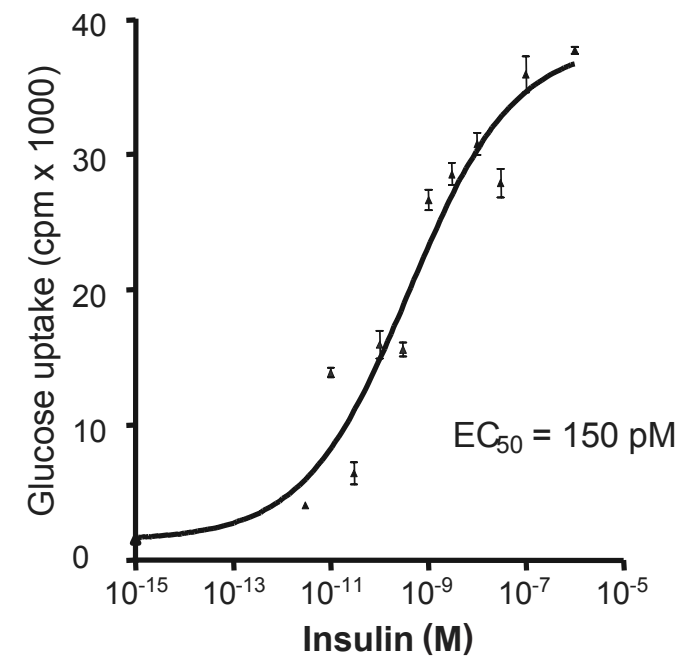

Fig. 3. PPAR $\gamma$-dependent differentiation and insulin-stimulated glucose uptake. A Stimulation with rosiglitazone: intracellular accumulation of triglycerides. B Glucose uptake is increase several-fold upon insulin stimulation.

A

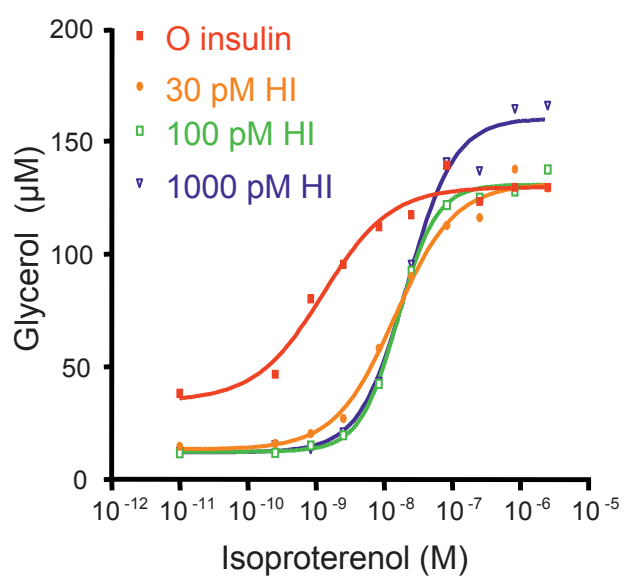

Fig. 4. Glycerol (A, B) and fatty acid mobilization (C, D) from SGBS adipocytes in response to different combinations of isoproterenol and insulin. $(\mathbf{A}, \mathbf{C})$ doseresponse curves for isoproterenol at fixed insulin concentrations. (B, D) dose-response curves for the inhibitory effect of insulin at fixed isoproterenol concentrations.
C

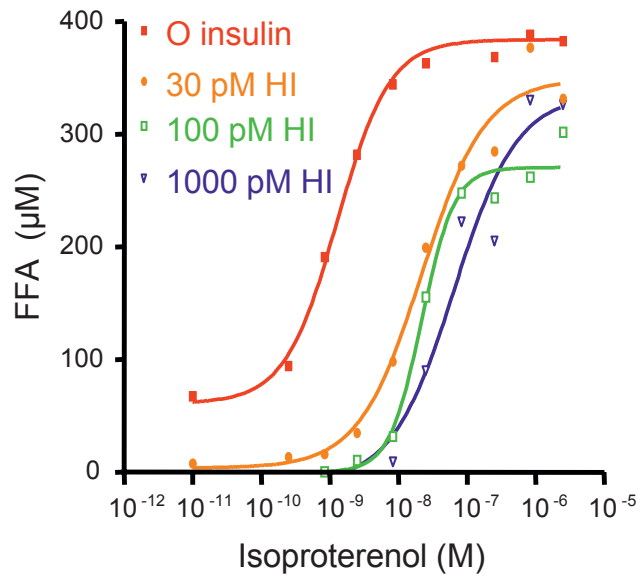

B

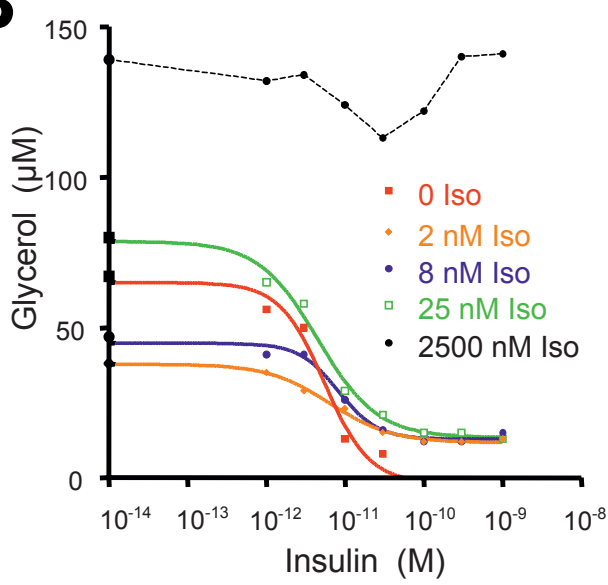

D

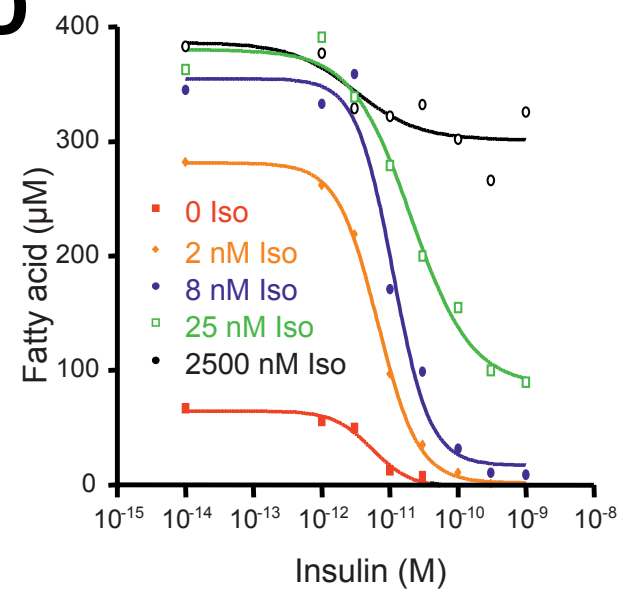


Table 2. Studies published so far using SGBS cells

\begin{tabular}{|c|c|c|}
\hline Year & Journal & Ref. \\
\hline 2001 & Int J Obes & [1] \\
\hline 2003 & Biochem Biophys Res Commun & [21] \\
\hline 2003 & J Lipid Res & [7] \\
\hline 2004 & Endocrinology & [18] \\
\hline 2004 & J Biol Chem & {$[12]$} \\
\hline 2005 & FEBS Lett & {$[22]$} \\
\hline 2005 & Biochim Biophas Acta & [8] \\
\hline 2005 & J Biol Chem & [23] \\
\hline 2005 & Inflamm Res & [24] \\
\hline 2005 & Prostaglandins Leukot Essent Fatty Acids & {$[24]$} \\
\hline 2005 & Biochem J & {$[5]$} \\
\hline 2005 & Biochem Biophys Res Commun & [19] \\
\hline 2005 & Horm Metab Res & [13] \\
\hline 2006 & J Clin Endocrinol Metab & {$[25]$} \\
\hline 2006 & Diabetes & [26] \\
\hline 2006 & J Clin Endocrinol Metab & [27] \\
\hline 2006 & Obesity & [14] \\
\hline 2006 & Am J Physiol Endocrinol Metab & {$[10]$} \\
\hline 2006 & J Lipid Res & [11] \\
\hline 2006 & Yonsei Med J & [17] \\
\hline 2006 & FASEB J & [6] \\
\hline 2007 & Horm Metab Res & [9] \\
\hline 2007 & Plos Med & [29] \\
\hline 2007 & Atherosclerosis & {$[15]$} \\
\hline 2007 & J Clin Endocrinol Metab & [28] \\
\hline 2007 & Cell Metab & {$[30]$} \\
\hline 2008 & Breast Cancer Res Treat & {$[20]$} \\
\hline 2008 & Arterioscler Thromb Vasc Biol & {$[31]$} \\
\hline
\end{tabular}

lipolysis, measured as release of glycerol and net fatty acid mobilization. Insulin was able to potently inhibit ( $\mathrm{IC}_{50}$ approximately $10-20 \mathrm{pmol} / \mathrm{l}$ ) submaximally stimulated lipolysis by isoproterenol $(2,8$, or $25 \mathrm{nmol} / \mathrm{l})$. These data are in accordance with those of primary rat adipocytes [3] showing again that maximal anti-lipolytic effects of insulin occur at submaximally stimulated lipolysis reflecting the changes in cAMP/ protein kinase activity.

\section{Some Study Data on Human Adipocyte Biology Using SGBS Cells}

Since their first description in 2001, SGBS cells have been distributed to about 100 research laboratories all over the world, and several studies using this cell line as a model system have been published so far (table 2). Functionally, SGBS adipocytes behave like adipocytes differentiated in vitro from human preadipocytes obtained from the subcutaneous adipose tissue of donors. The cells also show a comparable gene expression pattern [1]. So far, most insights of the scientific literature into adipogenic differentiation were obtained using murine model systems [4]. SGBS cells are suited to study adipogenic differentiation and factors influencing this process in a human sys- tem $[5,6]$. Furthermore, these cells provide a unique model system to investigate the influence of food compounds or drugs on human fat cell function. For example, we and others have studied the effect of different isomers of conjugated linoleic acids (CLA) on adipocyte biology [7-9]. CLA have been shown to reduce fat mass in animal and cell culture models. However, controversial results were obtained in studies of supplementation of CLA in human subjects. Granlund et al. [7] showed that the trans10, cis12 CLA isomer prevents lipid accumulation in adipocytes by acting as a PPAR $\gamma$ modulator. This inhibition of lipid accumulation is associated with a tight regulatory cross-talk between early (PPAR $\gamma$ and $\mathrm{C} / \mathrm{EBP} \alpha$ ) and late (LXR $\alpha, \mathrm{aP} 2$, and CD36) adipogenic marker genes [8]. Our group showed that CLA promote apoptosis in SGBS adipocytes [9]. Other compounds studied in SGBS cells include PPAR $\gamma$ agonist pioglitazone [10,11], PPAR $\alpha$ agonist fenofibrate [12], human immunodeficiency virus (HIV) protease inhibitors ritonavir and atazanavir [13, 14], and HMGCoA reductase inhibitor rosuvastatin [15].

In the last decade, it became more and more clear that adipose tissue is more than an organ storing energy in the form of triglycerides. It is now well recognized as an endocrine organ secreting more than 100 different factors [16]. Depending on the state of adipogenic differentiation, SGBS cells secrete a plethora of adipokines such as interleukins [13, 14, 17], insulinlike growth factor-1 (IGF-1) [18], plasminogen activator inhibitor-1 [15], leptin, and adiponectin [10,13, 19]. Using SGBS adipocytes as model system, we studied the regulation of adiponectin expression [19]. Adiponectin was not expressed by human preadipocytes. Differentiation into adipocytes was necessary to induce an increasing expression of adiponectin in parallel to an increasing expression of adipocyte differentiation markers. Adiponectin protein synthesis and secretion occurred specifically in mature adipocytes, and may thus serve as a distinctive marker of adipocyte differentiation. Addition of serum during the course of differentiation as well as acutely to mature adipocytes significantly and concentration-dependently suppressed adiponectin to almost non-detectable levels, suggesting a strong humoral serum component of adiponectin down-regulation. This serum component is present in both obese and lean individuals with a tendency to a stronger effect in obese men and women. Withdrawal of adipogenic ingredients from the culture medium also resulted in a decrease of adiponectin expression and secretion, respectively. We identified insulin as a critical component to maintain adiponectin expression. Furthermore, pioglitazone was shown to increase secretion of high-molecular-weight adiponectin from adipocytes [10]. Ritonavir, a HIV protease inhibitor, reduced adiponectin expression $[13,14]$.

Interestingly, an Australian group has recently shown that aromatase, a member of the cytochrome P450 superfamily of enzymes which catalyses the rate-limiting step in the biosynthesis of estrogens, is expressed in SGBS preadipocytes [20]. Its expression and activity are strongly stimulated by forskolin 
(FSK) and phorbol 12-myristate-13-acetate (PMA) treatment. These findings are comparable to those obtained in isolated primary human preadipocytes [20], and demonstrate that SGBS cells are a valuable model to study this specific endocrine function of preadipocytes and adipocytes.

\section{Conclusion}

The primary human SGBS preadipocyte cell strain offers an almost unlimited source of homogeneous human preadipo- cytes with high differentiation capacity. The cells have not been transformed or immortalized. They are easily cultivated in 96/384-well plates with high reproducibility, and are differentiated in the absence of any added serum or albumin. Once differentiated, the cells function and behave as mature adipocytes and show optimal responses in key functional assays. The exact molecular alteration behind the increased capacity to proliferate with retained ability to differentiate is at present not known. In conclusion, the human SGBS preadipocyte cell strain offers an excellent new tool for studies of human adipocyte biology.

\section{References}

1 Wabitsch M, Brenner RE, Melzner I, Braun M Moller P, Heinze E, Debatin KM, Hauner H: Characterization of a human preadipocyte cell strain with high capacity for adipose differentiation. Int $\mathbf{J}$ Obes Relat Metab Disord 2001;25:8-15.

2 DeBaun MR, Ess J, Saunders S: Simpson Golabi Behmel syndrome: progress toward understanding the molecular basis for overgrowth, malformation, and cancer predisposition. Mol Genet Metab 2001; 72:279-286.

3 Londos C, Honnor RC, Dhillon GS: cAMP-dependent protein kinase and lipolysis in rat adipocytes III. Multiple modes of insulin regulation of lipolysis and regulation of insulin responses by adenylate cyclase regulators. J Biol Chem 1985;260:15139_ 15145.

4 Rosen ED, MacDougald OA: Adipocyte differentiation from the inside out. Nat Rev Mol Cell Biol 2006;7:885-896.

5 Zandbergen F, Mandard S, Escher P, Tan NS, Patsouris D, Jatkoe T, Rojas-Caro S, Madore S, Wahli W, Tafuri S, Muller M, Kersten S: The G0/G1 switch gene 2 is a novel PPAR target gene. Biochem J 2005;392:313-324.

6 Newell FS, Su H, Tornqvist H, Whitehead JP, Prins JB, Hutley LJ: Characterization of the transcriptional and functional effects of fibroblast growth factor-1 on human preadipocyte differentiation. FASEB J 2006;20:2615-2617.

7 Granlund L, Juvet LK, Pedersen JI, Nebb HI Trans10, cis12-conjugated linoleic acid prevents triacylglycerol accumulation in adipocytes by acting as a PPARgamma modulator. J Lipid Res 2003;44: 1441-1452.

8 Granlund L, Pedersen JI, Nebb HI: Impaired lipid accumulation by trans10, cis12 CLA during adipocyte differentiation is dependent on timing and length of treatment. Biochim Biophys Acta 2005; 1687:11-22.

9 Fischer-Posovszky P, Kukulus V, Zulet MA, Debatin KM, Wabitsch M: Conjugated linoleic acids promote human fat cell apoptosis. Horm Metab Res 2007;39:186-191.

10 Bodles AM, Banga A, Rasouli N, Ono F, Kern PA, Owens RJ: Pioglitazone increases secretion of highmolecular-weight adiponectin from adipocytes. Am J Physiol Endocrinol Metab 2006;291:E1100-1105.

11 Bodles AM, Varma V, Yao-Borengasser A, Phanavanh B, Peterson CA, McGehee RE Jr, Rasouli N, Wabitsch M, Kern PA: Pioglitazone induces apoptosis of macrophages in human adipose tissue. $\mathrm{J}$ Lipid Res 2006;47:2080-2088.

12 Mandard S, Zandbergen F, Tan NS, Escher P, Patsouris D, Koenig W, Kleemann R, Bakker A, Veenman F, Wahli W, Muller M, Kersten S: The direct peroxisome proliferator-activated receptor target fasting-induced adipose factor (FIAF/PGAR/ ANGPTL4) is present in blood plasma as a truncated protein that is increased by fenofibrate treatment. J Biol Chem 2004;279:34411-34420.

13 Grigem S, Fischer-Posovszky P, Debatin KM, Loizon E, Vidal H, Wabitsch M: The effect of the HIV protease inhibitor ritonavir on proliferation, differentiation, lipogenesis, gene expression and apoptosis of human preadipocytes and adipocytes. Horm Metab Res 2005;37:602-609.

14 Kim RJ, Wilson CG, Wabitsch M, Lazar MA, Steppan CM: HIV protease inhibitor-specific alterations in human adipocyte differentiation and metabolism. Obesity (Silver Spring) 2006;14:994-1002.

15 Laumen H, Skurk T, Hauner H: The HMG-CoA reductase inhibitor rosuvastatin inhibits plasminogen activator inhibitor-1 expression and secretion in human adipocytes. Atherosclerosis 2008;196: $565-573$.

16 Fischer-Posovszky P, Wabitsch M, Hochberg Z: Endocrinology of adipose tissue - an update. Horm Metab Res 2007;39:314-321.

17 Do MS, Jeong HS, Choi BH, Hunter L, Langley S, Pazmany L, Trayhurn P: Inflammatory gene expression patterns revealed by DNA microarray analysis in TNF-alpha-treated SGBS human adipocytes. Yonsei Med J 2006;47:729-736.

18 Fischer-Posovszky P, Tornqvist H, Debatin KM, Wabitsch M: Inhibition of death-receptor mediated apoptosis in human adipocytes by the insulin-like growth factor I (IGF-I)/IGF-I receptor autocrine circuit. Endocrinology 2004;145:1849-1859.

19 Korner A, Wabitsch M, Seidel B, Fischer-Posovszky P, Berthold A, Stumvoll M, Bluher M, Kratzsch J, Kiess W: Adiponectin expression in humans is dependent on differentiation of adipocytes and downregulated by humoral serum components of high molecular weight. Biochem Biophys Res Commun 2005;337:540-550.

20 McInnes KJ, Brown KA, Knower KC, Chand AL, Clyne CD, Simpson ER: Characterisation of aromatase expression in the human adipocyte cell line SGBS. Breast Cancer Res Treat 2008; DOI: 10.1007/s10549-007-9883-2.

21 Wood IS, Hunter L, Trayhurn P: Expression of Class III facilitative glucose transporter genes (GLUT-10 and GLUT-12) in mouse and human adipose tissues. Biochem Biophys Res Commun 2003;308:43-49.

22 Bao Y, Bing C, Hunter L, Jenkins JR, Wabitsch M, Trayhurn P: Zinc-alpha2-glycoprotein, a lipid mobilizing factor, is expressed and secreted by human (SGBS) adipocytes. FEBS Lett 2005;579:41-47.
23 Simon MF, Daviaud D, Pradere JP, Gres S, Guigne C, Wabitsch M, Chun J, Valet P, Saulnier-Blache JS: Lysophosphatidic acid inhibits adipocyte differentiation via lysophosphatidic acid 1 receptor-dependent down-regulation of peroxisome proliferatoractivated receptor gamma2. J Biol Chem 2005;280: 14656-14662.

24 Duttaroy AK, Jorgensen A: Insulin and leptin do not affect fatty acid uptake and metabolism in human placental choriocarcinoma (BeWo) cells. Prostaglandins Leukot Essent Fatty Acids 2005;72: 403-408.

25 Fischer-Posovszky P, Hebestreit H, Hofmann AK, Strauss G, Moller P, Debatin KM, Wabitsch M: Role of CD95-mediated adipocyte loss in autoimmune lipodystrophy. J Clin Endocrinol Metab 2006;91: 1129-1135.

26 Johansson LE, Hoffstedt J, Parikh H, Carlsson E, Wabitsch M, Bondeson AG, Hedenbro J, Tornqvist $\mathrm{H}$, Groop L, Ridderstrale M: Variation in the adiponutrin gene influences its expression and associates with obesity. Diabetes 2006;55:826-833.

27 Wei Y, Rhani Z, Goodyer CG: Characterization of growth hormone receptor messenger ribonucleic acid variants in human adipocytes. J Clin Endocrinol Metab 2006;91:1901-1908.

28 Korner A, Garten A, Bluher M, Tauscher R, Kratzsch J, Kiess W: Molecular characteristics of serum visfatin and differential detection by immunoassays. J Clin Endocrinol Metab 2007;92: 4783-4791.

29 Parikh H, Carlsson E, Chutkow WA, Johansson LE, Storgaard H, Poulsen P, Saxena R, Ladd C, Schulze PC, Mazzini MJ, Jensen CB, Krook A, Bjornholm M, Tornqvist H, Zierath JR, Ridderstrale M, Altshuler D, Lee RT, Vaag A, Groop LC, Mootha VK: TXNIP regulates peripheral glucose metabolism in humans. PLoS Med 2007;4:e158.

30 Revollo JR, Korner A, Mills KF, Satoh A, Wang T, Garten A, Dasgupta B, Sasaki Y, Wolberger C, Townsend RR, Milbrandt J, Kiess W, Imai S: Nampt/PBEF/Visfatin regulates insulin secretion in beta cells as a systemic NAD biosynthetic enzyme. Cell Metab 2007;6:363-375.

31 Kintscher U, Hartge M, Hess K, Foryst-Ludwig A, Clemenz M, Wabitsch M, Fischer-Posovszky P, Barth TF, Dragun D, Skurk T, Hauner H, Bluher M, Unger T, Wolf AM, Knippschild U, Hombach V, Marx N: T-lymphocyte infiltration in visceral adipose tissue. A primary event in adipose tissue inflammation and the development of obesity-mediated insulin resistance. Arterioscler Thromb Vasc Biol 2008;28:1304-1310. 